\title{
膵島ミトコンドリアを標的とした分子送達技術の開発及び糖尿病治療への展開
}

\author{
山田勇磨
}

\section{A Nanocarrier System for Mitochondrial Delivery Targeted to a Pancreatic Beta Cell}

\author{
Yuma Yamada \\ Faculty of Pharmaceutical Sciences, Hokkaido University; Kita-12 Nishi-6, Kita-ku, Sapporo 060-0812, Japan.
}

(Received July 20, 2018)

\begin{abstract}
The destruction of $\beta$ cells of pancreatic islets results in a reduced level of insulin secretion, thus resulting in the onset of diabetes. Diabetes caused by such a decrease in insulin secretion has been reported to be associated with mitochondrial dysfunction. Because of this, mitochondrial therapy would be expected to be a useful and productive strategy for the treatment of this disease. We previously reported the development of a MITO-Porter, a liposome-based nanocarrier that permits macromolecular cargos to be delivered into mitochondria via membrane fusion. In this presentation, we present our current findings on the development of a mitochondrial nanocarrier system aimed at the development of a novel method for treating and preventing diabetes. The system includes "a nanocarrier system for nucleic acids targeted to pancreatic $\beta$ cells", and "an in vivo system for the delivery of nucleic acids targeting the pancreas". In this presentation, we propose the use of a "mitochondrial nanocarrier system"' as a novel method for the treatment and prevention of diabetes, and discuss the contribution of mitochondrial nanocarrier systems to innovative drug development.
\end{abstract}

Key words — mitochondrial delivery; nanocarrier; pancreatic beta cell; diabetic; nanomedicine

\section{1. はじめに}

膵臓ランゲルハンス島（ラ氏島）に存在する膵 $\beta$ 細胞の破壊・機能不全はインスリンの枯渇及び分泌 低下を招き，糖尿病発症の原因となることが知られ ている. 近年, ミトコンドリアの機能不全とインス リン分泌能低下を伴う糖尿病との関連が明らかと なってきており，本オルガネラを標的とした薬物治 療が注目されている.われわれは，ミトコンドリア を標的とした薬物送達システム（drug delivery system; DDS）の開発を進めており，膜融合を介して ミトコンドリア内部へ分子（核酸, タンパク質, 機 能分子，など）を送達するミトコンドリア融合性ナ ノカプセル MITO-Porter の構築に成功してい る. ${ }^{1-3)}$ 現在は, ミトコンドリア標的型 DDS による 『新規・糖尿病治療法・予防法の開発』を目指し, 「膵 $\beta$ 細胞への核酸導入 DDS の構築」, $\left.{ }^{4}\right) 「 i n$ vivo 応 用が可能なラ氏島への核酸導入法の確立」5)に関す

北海道大学大学院薬学研究院（０60-0812 札幌市北区 北 12 条西 6 丁目)

e-mail: u-ma@pharm.hokudai.ac.jp

本総説は, 日本薬学会第 138 年会シンポジウムS70 で

発表した内容を中心に記述したものである.
る研究を推進している。本稿では，われわれがこれ まで取り組んできた『ミトコンドリア標的型 DDS』 に関する研究「in vivo 応用が可能なラ氏島への核 酸導入法の確立」,「膵 $\beta$ 細胞への核酸導入 DDS の 構築」に関する研究成果を紹介する.

\section{2. ミトコンドリア標的型 DDS}

多彩な機能を有するミトコンドリアは，革新的な 疾患治療の実現，美容・健康の維持，ライフサイエ ンスの発展に大きく寄与するオルガネラとして注目 されている，これらの事業を実現するためには，ミ トコンドリアへ目的分子を送達する DDS が必要不 可欠であり，本 DDS の開発は，医療・ライフサイ エンス分野の発展に大きく貢献すると期待されてい る. 有用な DDS が多数開発されている核・細胞質 を標的とした研究では, タンパク質・遺伝子治療も 含め多数の実施例が報告されているが，ミトコンド

リアを標的とした疾患治療に関する DDS の報告は 皆無であり，疾患治療を実現するミトコンドリア標 的型 DDS の開発に大きな期待が寄せられていた.

このような背景の下，われわれはナノカプセル型 ミトコンドリア標的型 DDS, MITO-Porter に関す る研究を進めてきた。 MITO-Porter は膜融合を介 


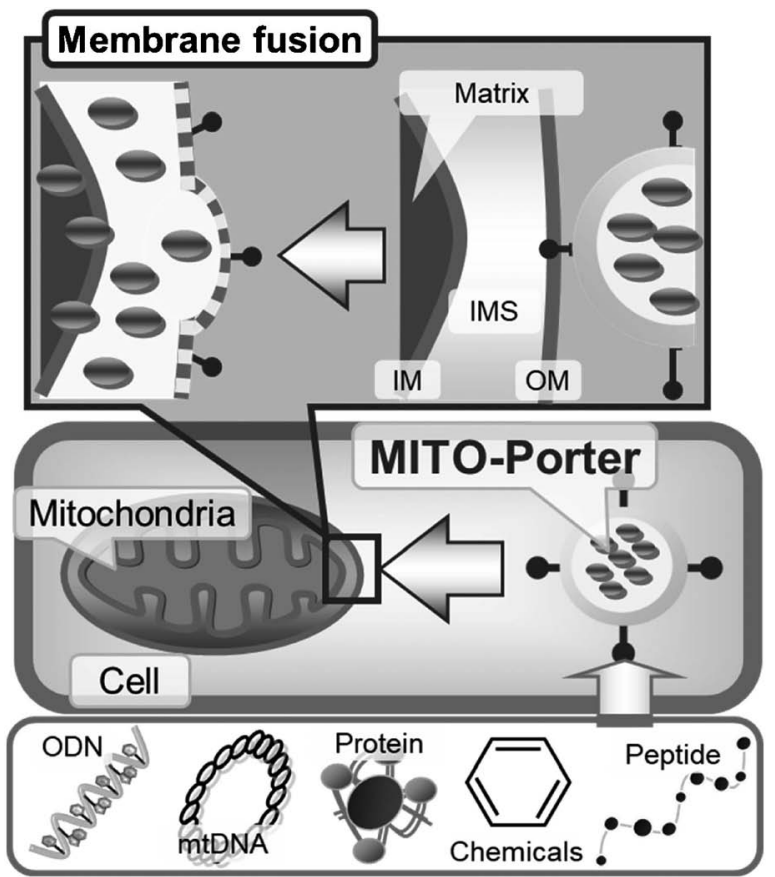

Fig. 1. Schematic Image of Mitochondrial Delivery by the MITO-Porter via Membrane Fusion ${ }^{2)}$

This figure is reused with permission from Elsevier.

してミトコンドリアに内封分子を送達するため，送 達分子の物性やサイズを制限しない DDS になり得 る (Fig. 1). ${ }^{1-3)}$ 本戦略を実現するために，膜融合 組成の探索を行い 100 種以上の組成の中から，ミト コンドリア高融合性ナノカプセル， MITO-Porter を構築することに成功し, ${ }^{1)}$ 特許を取得している (特許第 5067733 号)。ヒト皮膚由来ミトコンドリア 疾患細胞を用いて MITO-Porter の細胞内動態を観 察した際も，MITO-Porter は薬物をミトコンドリ アへ送達可能であることを確認している。

\section{In vivo 応用が可能なラ氏島への核酸導入法}

\section{の確立}

膵島ミトコンドリアまで核酸を送達するために は, 膵臓・膵島へのアクセス, 膵 $\beta$ 細胞内への導 入，ミトコンドリアへの送達，と多くの障壁を乗り 越える必要がある。まずは，第一の課題，膵 $\beta$ 細 胞を標的とした in vivo 核酸導入を目指した投与経 路の確立を行った。膵 $\beta$ 細胞を標的とした報告と して, 2006 年に 8 型アデノ随伴ウイルスを腹腔内 投与することで膵臓での遺伝子発現を達成したとい

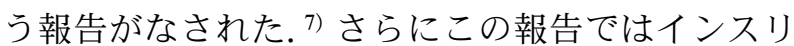
ンプロモーターを用いることで膵 $\beta$ 細胞特異的な 遺伝子発現に成功している。 しかしながらウイルス
が全身に分布することによる影響が不明である，搭 載遺伝子サイズに制限があるといつた課題もあり, 安全かつ簡便・効率的な手法を目指して，様々な角 度からのアプローチが必要であると考えられた。

われわれはその手法として，ハイドロダイナミク ス投与法に着目した。本投与法はマウス全血と同等 の体積に希釈したプラスミド DNA を尾静脈より急 速に投与することで肝臓において高い遺伝子発現が 得られることが報告されている，Liu らの報告によ ると肝臟以外に腎臓，脾臓，肺，心臓でも遺伝子発 現が認められていたことから, ${ }^{8)}$ ハイドロダイナミ クス投与時の膵臓における遺伝子発現を調べること とした.ルシフェラーゼ遺伝子をコードしたプラス ミド DNA，以下 pLuc $50 \mu \mathrm{g}$ をハイドロダイナミク ス投与し, $8 \mathrm{~h}$ 後に各臓器のルシフェラーゼ活性を 測定した。その結果，膵臓では $10^{6}$ 程度のルシフェ ラーゼ活性が認められたが，肝臓における活性 (10 $10^{8}$ 以上) に比べて低いということが明らかと なった. ${ }^{5}$

ハイドロダイナミクス投与では，一過的に組織・ 細胞膜の透過性が充進することで核酸導入が可能と なると考えられている。この原理を利用したままよ り膵臓選択的な遺伝子導入を達成するために，投与 経路を経胆管投与に変更した。肝臓と十二指腸をつ なぐ胆管は，その途中で主膵管に分岐して膵臓へ向 かっている. したがって，胆管と十二指腸の付け根 をクランプでとめ, 肝臟側から針を挿入し投与する ことで，膵臓へ局所的に薬液を行き渡らせることが できる [Fig. 2(A)]。この投与法を臨床へ応用する 際には，内視鏡的逆行性胆管膵管造影（endoscopic retrograde cholangiopancreatography; ERCP), を 想定している. ERCP は, 現在臨床で膵臓や胆管 に関する疾患を診断するための検査として利用され ている.この検査では内視鏡を口から十二指腸まで 進め，カニューレを挿管し，造影剂を注入する [Fig. 2(B)］。この技術を用いることで，Fig. 2(A) で示した経胆管投与と同様に，膵臓へ局所的に薬液 を投与することができると考えた.

経胆管投与を介して膵臓での遺伝子発現が得られ るかを検証した結果, 膵臓で $10^{6}-10^{7}$ のルシフェ ラーゼ活性が認められ，その活性は $1 \mu \mathrm{g}$ の投与量 で飽和していることが明らかとなった。また他藏器 における遺伝子発現は，膵臓での活性の $1 / 1000$ 以 
A

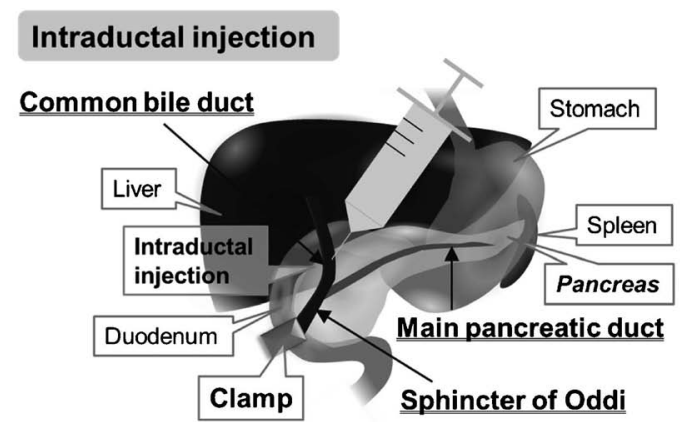

B

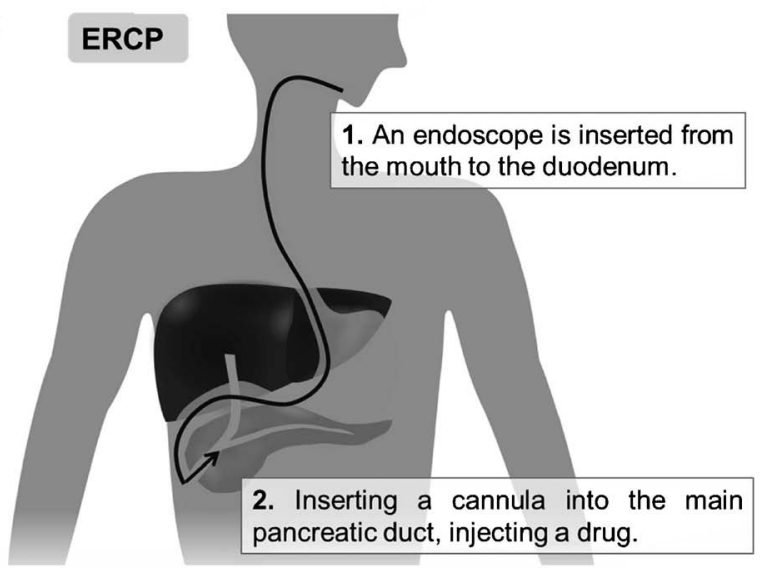

Fig. 2. Schematic Images of Gene Delivery to the Pancreas by Intraductal Injection and Endoscopic Retrograde Cholangiopancreatography (ERCP)

(A) Schematic diagram of intraductal injection of pDNA into common bile duct of mice. ${ }^{5)}$ This figure is reused with permission from Elsevier. (B) Schematic diagram of gene delivery to the pancreas by ERCP.

下と低く，経胆管投与は膵臓選択的な遺伝子導入が 可能であることが示唆された（Fig. 3)。本投与法 を最適化するために投与体積と投与速度が遺伝子発 現に与える影響について調べた。 その結果，投与体 積は $50 \mu \mathrm{L}$ で，投与速度は 5 秒間かけて投与した際 に最も高いルシフェラーゼ活性が得られた。このよ うに，経胆管投与には最適な投与体積と投与速度が あることが明らかとなり，膵臓への効率的な核酸導 入法を確立することに成功した. ${ }^{5)}$

ここまでは経胆管投与による膵臓全体での遺伝子 発現に関する結果を示したが，膵 $\beta$ 細胞まで核酸 を届けるにはここからさらに膵臓内部に存在する膵 島まで到達する必要がある。そこで，経胆管投与に より導入した核酸が膵島まで到達しているかを調べ た。本評価にあたって，pLuc 投与マウスよりコラ ゲナーゼ処理を施し膵島を単離し，単離した膵島か ら total RNA を抽出し, 逆転写 PCR を行った。 そ の結果，pLuc を投与したサンプルでルシフェラー ゼ mRNAの増幅産物が検出された。 ${ }^{5)}$ 以上, 経胆

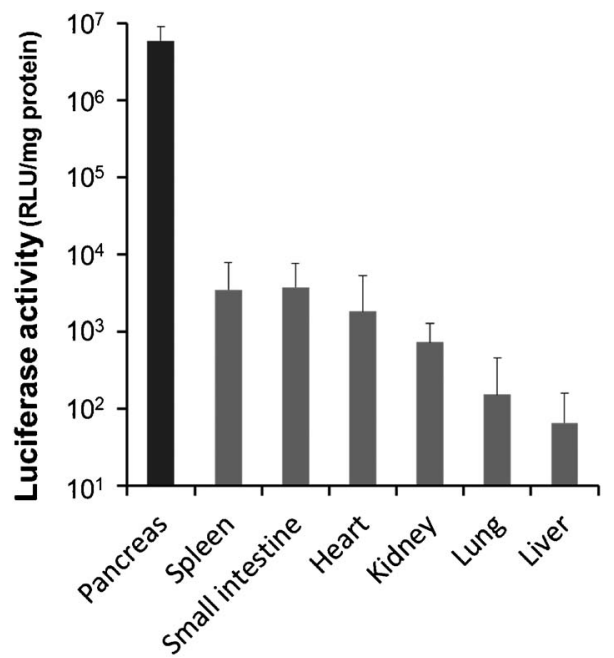

Fig. 3. Investigation of Gene Expression in the Pancreas and Various Tissues following the Intraductal Injection of Naked pDNA $^{5)}$

After intraductal injection of $1 \mu \mathrm{g}$ pDNA in $50 \mu \mathrm{L}$ saline in $5 \mathrm{~s}$, the tissues including liver, spleen, kidney, lung, heart, pancreas and small intestine were harvested at $24 \mathrm{~h}$ post injection, and luciferase activities were measured. Bars indicate the means \pm S.D. $(n=3)$. This figure is reused with permission from Elsevier.

管投与により膵臓選択的な遺伝子発現を達成し，さ らに本投与経路を介した膵島への核酸導入が示唆さ れた。

\section{4. 脺 $\beta$ 細胞への核酸導入 DDS の構築}

ここからは, 膵 $\beta$ 細胞内部への核酸送達研究に ついて紹介する．筆者の所属する北海道大学大学院 薬学研究院・薬剤分子設計学研究室では核酸キャリ アとして多機能性エンベロープ型ナノ構造体 (multifunctional envelope-type nano device; MEND) の開発を進めている. ${ }^{9,10)}$ MEND は脂質膜でできた リポソームの中にナノ粒子化核酸を封入した構造を 有している（Fig. 4)。MENDの表面に細胞導入促 進ペプチドであるオクタアルギニン（octaarginine; R8）を修飾した R8-MEND は，ヒト子宮頸がん細 胞 HeLa 細胞を始めとする, 複数の細胞種に対して 効率的な核酸導入に成功している。はじめに，本 MEND システムを基盤とし，膵 $\beta$ 細胞を標的とし た DDS の構築を進めることとした.

膵 $\beta$ 細胞モデルとして MIN6 細胞を用い，蛍光 標識した R8-MEND の細胞取り込みをフローサイ トメトリーを用いて評価した。 R8-MENDは， HeLa 細胞で効率的な細胞取り込みが観察されたが, MIN6 細胞に対しては細胞取り込みはほとんぞ観察 されなかった. ${ }^{4)}$ そのため, エンベロープ膜への R8 


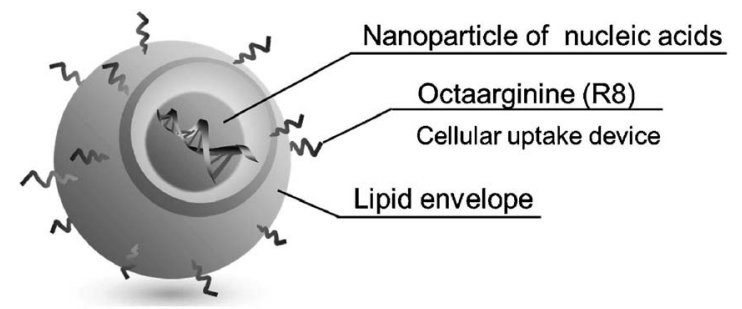

Fig. 4. Schematic Representation of Multifunctional Envelope-type Nano Device (MEND)

修飾ではなく，「MEND を構成するエンベロープの 表面構造に MIN6 細胞への親和性を付加する」と いう戦略を検討することにした．脂質の種類や組み 合わせを変化させることで多様な表面構造を有する 脂質膜エンベロープ（リポソーム）を調製すること が可能となる．本検討では負電荷を有する細胞膜と 相互作用するためのカチオン性脂質，リポソームを 形成し易い構造を持つメイン脂質，リポソームの表 面構造に更なる多様性を持たせるためのヘルパー脂 質の 3 群より脂質を組み合わせ，複数種のリポソー ムを調製した。探索の結果, ヘルパー脂質の sphingomyelin（SM), カチオン性脂質の $3 \beta-\left[N-\left(N^{\prime}, N^{\prime}-\right.\right.$ dimethylaminoethane) -carbamoyl] cholesterol (DCChol）, メイン脂質の egg phosphatidylcholine (EPC) を 3/3/4 の割合で混合したリポソームが MIN6 細胞に対して最も高い取り込みを示した。最 適化した脂質膜エンベロープからなる MEND を膵 $\beta$ 細胞に特化した MEND, $\beta$-MEND と命名した.

$\beta$-MEND の MIN6 細胞への核酸導入量を評価し たところ, 従来の R8-MEND 及び市販の核酸導入 試薬であるリポフェクタミンプラスと比較して高い 核酸導入能が示された（Fig. 5)。次に $\beta$-MENDに より導入された核酸が細胞内で機能することができ る状態にあるのかを検証した。本実験では phosphoinositide-dependent protein kinase 1 (PDK1), myotrophin（MTPN）と呼ばれるタンパク質の発 現抑制を介して，インスリン分泌を負に制御する microRNA，miR-375 を標的とした。 アンチセンス 核酸が細胞内で機能すると, miR-375 の発現が低下 し，その結果インスリン分泌量が上昇することが予 想される。 $\beta$-MEND を用いてアンチセンス核酸を MIN6 細胞へ導入した結果, リポフェクタミンプラ スを用いた場合と比較して，より強い miR-375の 発現抑制, インスリン分泌量の増加が観察された。

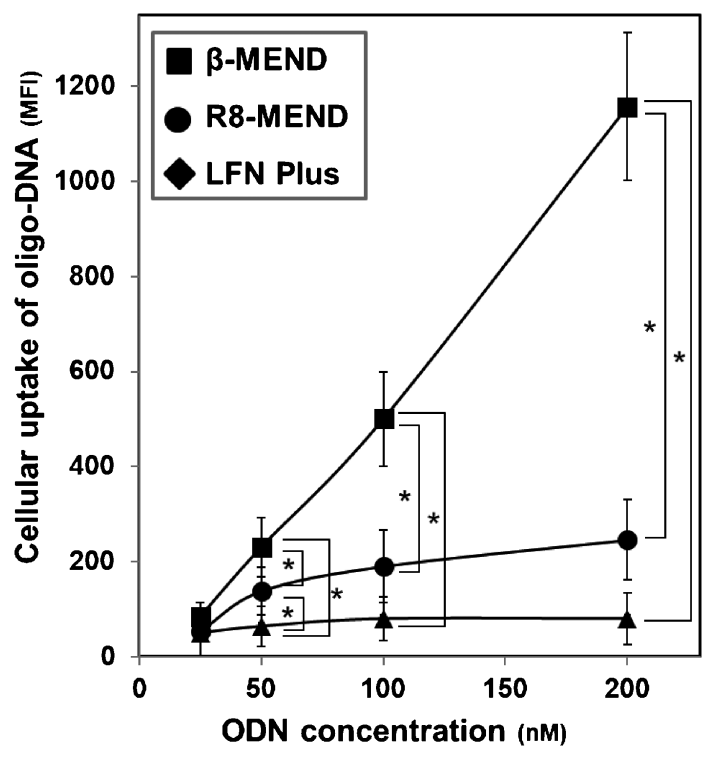

Fig. 5. Cellular Uptake Analysis and Intracellular Observation of $\beta$-MEND in MIN6 Cells ${ }^{5)}$

MFI, mean fluorescence intensity. Data are represented as the mean \pm S.D. $(n=3-6)$ *Significant differences $(p<0.01)$ were calculated by oneway ANOVA, followed by Student-Newman-Keuls (SNK) test. This figure is reused with permission from Elsevier.

これらの結果から， $\beta$-MENDによって導入された 核酸は細胞内で機能することが可能であると結論し た.

\section{5. おわりに}

本総説では, 『若手が取り組む新規糖尿病治療・ 予防法の開発を目指した研究戦略』のテーマの 1 つ として『膵島ミトコンドリアを標的とした分子送達 技術の開発』に関する研究をわれわれの研究成果を 中心に紹介してきた。本稿で紹介した『ミトコンド リア標的型 $\mathrm{DDS} 』, 「 i n$ vivo 応用が可能なラ氏島へ の核酸導入法の確立」,「膵 $\beta$ 細胞への核酸導入 DDS の構築」に関する研究は独立した研究として それぞれの成果を得ている. 今後はこれらの技術を 統合し, 膵島・膵 $\beta$ 細胞のミトコンドリアを標的 可能な DDS を構築し, 新しいアプローチから糖尿 病治療に挑戦したいと考えている。本稿で紹介した 『膵島ミトコンドリアを標的とした分子送達技術』 に関する研究が，『新規・糖尿病治療法・予防法の 開発』を目指した研究戦略の 1 つとして認識頂き, 次世代創薬に関する議論のトピックとなれば幸いで ある。

謝辞林めに日本薬学会 第 138 年会シンポ ジウム『若手が取り組む新規糖尿病治療・予防法の 
開発を目指した研究戦略』における発表及び本総説 を執筆する貴重な機会を与えて頂きましたオーガナ イザーの大阪大谷大学・清水かほり先生, 熊本大学 大学院・鬼木健太郎先生に御礼申し上げます，本研 究は, 北海道大学大学院薬学研究院 - 原島秀吉教授 の主宰される薬剤分子設計学研究室において遂行さ れました.ご指導・ご鞭撻を賜りました原島教授, 並びに，いつもご協力頂いております同研究室のス タッフ・学生の皆様に心より感謝申し上げます。ま た，膵島を標的とする核酸送達に研究を精力的に進 めてくれた同研究室・田端麻衣修士（現 アステラ ス製薬）並びにミトコンドリアチームの皆様に厚く 御礼申し上げます。

利益相反＼cjkstart開示すべき利益相反はない.

\section{REFERENCES}

1) Yamada Y., Akita H., Kamiya H., Kogure K., Yamamoto T., Shinohara Y., Yamashita K., Kobayashi H., Kikuchi H., Harashima H., Biochim. Biophys. Acta, 1778, 423-432 (2008).

2) Yamada Y., Akita H., Harashima H.,
Methods Enzymol., 509, 301-326 (2012).

3) Yamada Y., Harashima H., Handb. Exp. Pharmacol., 240, 457-472 (2017).

4) Yamada Y., Tabata M., Yasuzaki Y., Nomura M., Shibata A., Ibayashi Y., Taniguchi Y., Sasaki S., Harashima H., Biomaterials, 35, 6430-6438 (2014).

5) Yamada Y., Tabata M., Abe J., Nomura M., Harashima H., J. Pharm. Sci., 107, 647-653 (2018) .

6) Yamada Y., Burger L., Kawamura E., Harashima H., Biol. Pharm. Bull., 40, 21832190 (2017).

7) Wang Z., Zhu T., Rehman K. K., Bertera S., Zhang J., Chen C., Papworth G., Watkins S., Trucco M., Robbins P. D., Li J., Xiao X., Diabetes, 55, 875-884 (2006).

8) Liu F., Song Y., Liu D., Gene Ther., 6, 12581266 (1999).

9) Kogure K., Moriguchi R., Sasaki K., Ueno M., Futaki S., Harashima H., J. Control. Release, 98, 317-323 (2004).

10) Sato Y., Nakamura T., Yamada Y., Harashima H., J. Control. Release, 244, 194-204 (2016). 